\title{
Mita Choudhury
}

The Wanton Jesuit and the Wayward Saint: A Tale of Sex, Religion, and Politics

in Eighteenth-Century France. University Park: Pennsylvania State Press, 2015.

Pp. xiii + 234. Hb, \$64.95.

In the fall of 1730, Catherine Cadière, a young woman with a growing reputation as a holy figure and mystic, accused Jean-Baptiste Girard, her Jesuit spiritual director, of seduction, heresy, abortion, and bewitchment. The resulting investigation and court case became a cause célèbre that reverberated from the provincial French port city of Toulon where it originated to the halls of Versailles and beyond. In the decades that followed, the Cadière scandal continued to resonate in the public sphere, serving as one inspiration for Jean Baptiste de Boyer's famous pornographic novel, Thérèse philosophe (Paris: Fayard, 1986). In this well-conceived and engagingly written microhistory, Mita Choudhury explores this affair in all its rich detail. In doing so she brings to light how a salacious sex scandal that fascinated the public for years became a focus for broader debates about the Jesuits and the place of religious and political authority in French society.

Through Choudhury's careful analysis it becomes clear that many of the underlying issues that made the case so compelling to eighteenth-century contemporaries also make it of real interest to modern historians. While seemingly a private affair, Girard's alleged abuse of his position of trust and the efforts of ecclesiastical and royal officials to shape the investigation led both Jansenist and philosophe supporters of Cadière to critique the foundations of traditional religious and political authority in the kingdom. The case also provides a relatively early example of the growing role of public opinion and an emerging public sphere in shaping French political, religious, and social discourse in the decades leading up to the French Revolution.

This book makes several useful contributions to Jesuit studies. First, it provides an example of how and why alleged scandalous behavior by an individual Jesuit became the subject of national interest and how his supposed misdeeds inspired broader attacks on the Society as an institution. Well-established anti-Jesuit narratives provided the context in which scandalous accusations like Cadière's resonated. However embarrassing, the Cadière affair did not fundamentally compromise the Society's mission and presence in France, but it did offer yet another example of Jesuit misconduct for their opponents, and in this way played a role in the Society's ultimate suppression in 1764 . Choudhury's study also shows how the Jesuits' close relationship with the monarchy was increasingly a liability in the decades following the death of Louis XIV, as Jesuit critics associated the Society with what they perceived as royal and 
sacerdotal despotism. Choudhury's analysis of the Cadière affair nicely complements Dale Van Kley's study of the Damiens assassination attempt on Louis $\mathrm{XV}$ in 1757 (The Damiens Affair and the Unravelling of the Ancien Régime, 17501770 [Princeton: Princeton University press, 1984]). In both cases, newsworthy events that captured the public's imagination became conduits for attacks on the Jesuit presence in France.

In the best micro-historical tradition, Choudhury is careful to present rival narratives created by supporters of both sides without establishing a single 'true' narrative. It remains an open question throughout whether Girard is guilty of the crimes or whether the accusations were fabricated by Cadière, her brothers, and other local opponents of the Society in Toulon. What comes out of this analysis is that at first both Cadière and Girard worked together to promote her as a saintly figure. Heroic religious partnerships like that between Jeanne de Chantal and her spiritual director François de Sales were an important feature of French dévot culture in the seventeenth century, providing ideal models for later aspiring saints and their spiritual counselors. But the dynamics of these close, personal relationships were fraught with potential danger for both parties. Cadière's private interactions with Girard left her open to scandalous rumors and accusations of deception. Meanwhile, Girard's critics accused the much older Jesuit of using his learning to corrupt his young charge, seducing her with mystical principles like "oubliez-vous, laissez-faire" (forget yourself, and let yourself go), which had Quietist overtones. Moreover, his detractors linked accusations of Girard's personal immorality to broader critiques of Jesuit casuistry and laxist ethical teachings. While the surviving evidence does not allow us to draw any firm conclusions concerning guilt, Girard certainly was responsible for putting himself and by association the Jesuits in a very difficult situation through his private interactions with Cadière. In this way, Girard reminds one less of François de Sales and more of another famous spiritual director, Urbain Grandier, the confessor of the Ursulines of Loudun who was ultimately burnt at the stake in 1634 for allegedly engaging in sexual improprieties with many of the nuns and bewitching or possessing his charges with demons. Interestingly, while the accusations of illicit sex, heresy, and abortion against Girard resonated in 1730s, complaints of witchcraft and possession leveled at the Jesuit early in the affair failed to stick. Nonetheless, the accusations were very similar to those that had cost Grandier his life, reminding us that the role of spiritual director was a risky position-especially for a Jesuit outsider in Toulon society.

Specialists will welcome this first full modern account of an important and in many ways representative cause célèbre of the sort that damaged the authority of the French church, the Jesuits, and the monarchy during the 
eighteenth century. But its audience will also be much wider, as it provides a rich window into many aspects of eighteenth-century French society, making it suitable for an undergraduate course. While some might wish that Choudhury had speculated further as to what actually happened between Cadière and Girard behind closed doors, her careful and judicious analysis takes the reader to the limits of the surviving trial records, printed pamphlets, circulating manuscripts, and private sources. In the end, what happened was less important than the broader debates the scandal sparked about the nature of religious and political authority in France.

\author{
Eric Nelson \\ Missouri State University \\ ericnelson@missouristate.edu \\ DOI 10.1163/22141332-00303008-18
}

